\title{
A comparative study of spot urine versus 24 hour urine in assessment of proteinuria in varying degree of renal dysfunction
}

\author{
Naufal Rizwan Taraganar Abubacker ${ }^{1 *}$, Sarfaraz Ahmed Taraganar Abubacker ${ }^{2}$, \\ Kannan Rajendran ${ }^{3}$, Senthil Manikandan Thirumanilayur Jayaraman ${ }^{1}$, \\ Prasanna Karthik Suthakaran ${ }^{1}$, Mahendrakumar Kalappan ${ }^{1}$
}

\footnotetext{
${ }^{1}$ Assistant Professor, ${ }^{3}$ Professor, General Medicine, Saveetha Medical College Hospital, Chennai, Tamilnadu, India

${ }^{2}$ Assistant Professor, General Medicine, SRM Medical College Hospital, Chennai, Tamilnadu, India
}

Received: 30 November 2015

Accepted: 12 December 2015

*Correspondence:

Dr. Naufal Rizwan Taraganar Abubacker,

E-mail: dr_naufal82@yahoo.co.in

Copyright: (C) the author(s), publisher and licensee Medip Academy. This is an open-access article distributed under the terms of the Creative Commons Attribution Non-Commercial License, which permits unrestricted non-commercial use, distribution, and reproduction in any medium, provided the original work is properly cited.

\begin{abstract}
Background: Proteinuria is a condition in which urine contains an excess amount of proteins. The gold standard test for evaluation of proteinuria is 24 hour urinary protein estimation which is a cumbersome process. The rate of urinary protein excretion remains variable and no standard values have been established for timed samples. However since it remains a very simple procedure to perform, evaluation of the predictive nature of the test in comparison to the 24 hour method is necessary. The aim of the study was to compare the 24 hour urinary protein excretion expected from 7 am and $7 \mathrm{pm}$ spot urine protein creatinine ratio with the estimated urine protein from a 24 hours urinary sample collection.

Methods: 55 patients with persistent dipstick positive proteinuria with varying degrees of renal dysfunction were included in this study. Two urine samples were collected, one in the early morning (around 7 am) and other in the evening (around $7 \mathrm{pm}$ ). Both samples were used to estimate protein - creatinine ratio and calculate expected 24 hours urinary protein excretion. 24 hours urine protein estimation was done simultaneously and compared.

Results: There was significant positive correlation with both the samples though the better correlation was seen in early morning urine sample than evening sample $(r=0.931$ for 7 am sample $\& \mathrm{r}=0.872$ in $7 \mathrm{pm}$ sample; $\mathrm{p}<0.01)$. The maximum correlation was seen in patients with normal/mild renal dysfunction and non nephrotic range proteinuria while it was lesser in patients with moderate/severe renal dysfunction and nephrotic range proteinuria.

Conclusions: Spot Urine Protein Creatinine Ratio may be used as an alternative for the 24 hour urinary protein excretion as it has a good correlation with the longer method. The early morning sample may be a preferable one.
\end{abstract}

Keywords: Protein -creatinine ratio, Proteinuria, Urine analysis, 24 hours urinary protein

\section{INTRODUCTION}

Proteinuria is a condition in which urine contains an excess amount of proteins. Normal individuals usually excrete very small amounts of protein in the urine(less than $150 \mathrm{mg} /$ day). ${ }^{1}$ Evaluation of proteinuria is often triggered by a positive dipstick on routine urine analysis. ${ }^{2}$ Proteinuria has fast become a common presentation of renal disease since dipstick testing for protein became widely available, and there is widespread screening of apparently healthy individuals. Urine is tested routinely during medical consultations for any complaint, during pregnancy, during insurance examinations, and on entry into many forms of employment such as the armed forces. ${ }^{3}$ The prevalence of proteinuria on a routine screening of healthy subjects has been found to be as high as $3.5 \%$. Considerable evidence accrued over the past decade suggests that the presence of even small quantities of protein or albumin in the urine is an important and early sign of kidney disease and has been shown to be an early 
predictor of increased risk for cardiovascular mortality and morbidity in certain high risk groups. ${ }^{4}$ Persistent proteinuria of more than $1.0 \mathrm{gm} /$ day in any adult is not only suggestive of the existence of renal disease but also of an increased risk of myocardial infarction and stroke. ${ }^{5}$ In particular, an increase in protein excretion is of diagnostic and prognostic significance in the detection and confirmation of renal disease. Quantification of the same may be of considerable value in assessing the effectiveness of therapy and the progression of the disease. ${ }^{6}$ So quantification of proteins in urine is very important. It is imperative that all patients with proteinuria be carefully evaluated to identify the etiology of proteinuria. Current methods for measuring proteinuria vary significantly. Commonly used methods are dipstick urine analysis, $24 \mathrm{hrs}$ urine protein estimation and spot urine protein Creatinine ratio. The most common method for quantification of proteinuria is estimation of $24 \mathrm{hrs}$ urinary protein in a urine specimen collected over $24 \mathrm{hrs}$. However, 24hr urinary protein estimation method has certain pitfalls and thus leads to discarding of nearly $1 / 3 \mathrm{rd}$ of the samples. To obviate these difficulties, short timed urine collection has been advocated with the hypothesis that protein excretion is nearly constant throughout the day. Very few Indian studies have compared the efficacy of 24 hours urine protein with spot urine protein creatinine ratio, which this study attempts to do.

The aim of the study was to compare the 24 hour urinary protein excretion expected from 7 am and 7 pm spot urine protein creatinine ratio with the estimated urine protein from a 24 hours urinary sample collection.

The objectives of the study were:

1. To calculate the expected 24 hour urinary protein excretion of the patient from the Protein Creatinine Ratio of 7 am and 7 pm urine samples.

2. To estimate the 24 hour urinary protein excretion in the patient by a 24 hour urine sample collection.

3. To estimate the correlation between the expected and estimated values.

\section{METHODS}

55 patients, aged above 14 years, with persistent dipstick positive proteinuria, admitted in medical wards of a tertiary care hospital were included in the study. Persistent dipstick positive proteinuria was defined as positive urinary dipstick on 2 different occasions at least 1 week apart. Patients of age less than 14 years, patients with macroscopic hematuria, patients with febrile illness, dehydration, patients performing intensive muscular activity and patients with head injury were excluded from the study. A detailed history of the illness was elicited and recorded, general physical examination and systemic examination was done and findings recorded. Patients were advised to give their first morning urine sample for estimation of urine protein - Creatinine ratio. Then, their 24 hours urine was collected, including the last void urine at the end of 24 hours. A small sample of the urine ( 1 1ml) was taken around 7 PM for estimation of urine protein creatinine ratio. The patients were divided into 5 groups based on their eGFR based on the K/DOQI 2002 classification (Table 1). The data was collected and analysed by appropriate statistical tests using SPSS for Windows version 20.

\section{RESULTS}

Table 1: Stages of CKD based on EGFR (K/DOQI Classification).

\begin{tabular}{|ll|}
\hline Stages of CKD & $\begin{array}{l}\text { Estimated glomerular } \\
\text { filtration rate }(\mathrm{mL} / \mathrm{min})\end{array}$ \\
\hline Stage 1 & eGFR $\geq 90$ \\
\hline Stage 2 & $60 \leq \mathrm{eGFR}<89$ \\
\hline Stage 3 & $30 \leq \mathrm{eGFR}<59$ \\
\hline Stage 4 & $15 \leq \mathrm{eGFR}<29$ \\
\hline Stage 5 & eGFR $<15$ \\
\hline
\end{tabular}

Table 2: Distribution of patients based on degree of proteinuria.

\begin{tabular}{|lll|}
\hline $\begin{array}{l}\text { Degree of } \\
\text { proteinuria }\end{array}$ & $\begin{array}{l}\text { Protein } \\
\text { excretion/day }\end{array}$ & Patients \\
\hline Minimal & Less than $1 \mathrm{gm}$ & $7(12.72 \%)$ \\
\hline Moderate & 1 to 3 gm & $28(50.90 \%)$ \\
\hline Heavy & More than 3 gm & $20(36.36 \%)$ \\
\hline
\end{tabular}

Table 3: Paired Sample Statistics from $7 \mathrm{am} / 7 \mathrm{pm}$ samples.

\begin{tabular}{|c|c|c|c|c|c|c|}
\hline & \multicolumn{3}{|c|}{7 AM sample } & \multicolumn{3}{|c|}{7 PM sample } \\
\hline & Mean & Std. deviation & Correlation & Mean & Std. deviation & Correlation \\
\hline $\begin{array}{l}\text { Expected } 24 \text { hours urinary } \\
\text { protein }(\mathrm{gm})\end{array}$ & 3.36 & 2.46 & \multirow{2}{*}{$\begin{array}{l}0.931 \\
(\mathrm{P}<0.01)\end{array}$} & 3.46 & 2.27 & \multirow{2}{*}{$\begin{array}{l}0.872 \\
(P<0.01)\end{array}$} \\
\hline $\begin{array}{l}\text { Estimated } 24 \text { hours urinary } \\
\text { protein(gm) }\end{array}$ & 3.25 & 1.96 & & 3.26 & 1.96 & \\
\hline
\end{tabular}


Table 4: Correlation between expected 24 hours urinary protein from $7 \mathrm{am} / 7 \mathrm{pm}$ sample and estimated urinary protein in various degrees of proteinuria.

\begin{tabular}{|llllll|}
\hline $\begin{array}{l}\text { Degree of } \\
\text { proteinuria }\end{array}$ & $\mathbf{N}$ & 7 AM sample & \multicolumn{3}{c|}{ 7 PM sample } \\
\hline Minimal & 7 & Correlation & P value & Correlation & P value \\
\hline Moderate & 20 & 0.881 & 0.03 & .815 & 0.01 \\
\hline Heavy & 28 & 0.867 & $<0.01$ & .763 & 0.03 \\
\hline
\end{tabular}

Table 5: Correlation between expected 24 hours urinary protein from $7 \mathrm{am} / 7 \mathrm{pm}$ sample and estimated urinary protein in various stages of CKD.

\begin{tabular}{|llllll|}
\hline Stages of CKD & $\mathbf{N}$ & 7 AM sample & & 7 PM sample \\
\hline Stage 1 & 8 & Correlation & P value & Correlation & P value \\
\hline Stage 2 & 5 & 0.939 & $<0.01$ & 0.941 & 0.005 \\
\hline Stage 3 & 14 & 0.927 & 0.02 & 0.886 & 0.02 \\
\hline Stage4 & 26 & 0.945 & 0.04 & 0.878 & 0.01 \\
\hline Stage5 & 2 & 0.637 & 0.02 & 0.820 & 0.04 \\
\hline
\end{tabular}

55 patients were enrolled in the study. 32 patients were males and 23 patients were females. 13 patients were between 15 - 30 years of age, 29 were between $30-60$ years and 13 patients were above 60 years. The 24 hours urinary protein excretion was graded in to minimal, moderate and heavy as given in Table 2 . The patients were sub divided into groups based on their stage of CKD.

There was good positive correlation between spot urine Protein creatinine ratio of both samples taken at two different times of the day and estimated 24 hours urinary protein though the best correlation was seen in early morning urine sample than evening sample $(r=0.931$ in $7 \mathrm{AM} \& \mathrm{r}=0.872$ in $7 \mathrm{PM} ; \mathrm{p}<0.01)$ [Table 3].

The maximum correlation was seen in patients with normal/mild renal dysfunction and non nephrotic range proteinuria. The positive correlation was least in patients with moderate/severe renal dysfunction and nephrotic range proteinuria [Table 4,5]. The correlations were all statistically significant with $\mathrm{P}$ values less than 0.05 .

\section{DISCUSSION}

Measurement of urinary proteins over 24 hours is the definitive method to quantify proteinuria. However, prolonged collections of urine are inconvenient and often inaccurate due to frequent collection errors. ${ }^{7}$ In this study, we estimated protein creatinine ratio from two urine samples, one in the early morning first sample and one in the evening around 12 hours later. We estimated quantitative proteinuria from both samples using PCR values and analysed which correlates best with 24 hours urinary protein value. Although both morning and evening sample correlated well with 24 hours urine protein the degree of correlation was better with early morning urine sample $(\mathrm{r}=0.931)$ than with the evening sample $(r=0.872)$. The result of the study was consistent with the findings of Silink et al and Ginsberg et al who found that the correlation was best in early morning first sample. ${ }^{8,9}$ Rodby et al however showed that the timing of collection of urine sample did not impact on the ability to predict 24 hours urinary protein. ${ }^{10}$

The findings of this study differ from Koopman et al who observed that the usefulness of the protein creatinine ratio of a random urine sample for estimation of proteinuria is limited, because of the circadian rhythm of proteinuria. ${ }^{11}$ The greatest differences were seen during the times when the patients were most likely to be recumbent. In this study, spot urine samples were taken when the patients were rising from the recumbent posture $(7 \mathrm{am})$ and when they were ambulatory $(7 \mathrm{pm})$ and both correlates well with 24 hours proteinuria.

The study also showed that the best correlation was in patients with minimal to moderate proteinuria in $7 \mathrm{AM}$ sample $(r=0.881$ in group 1 and $r=0.867$ in group 2) and 7 PM sample ( $r=0.815$ in group 1 and $r=0.763$ in group 2). The positive correlation was least in patients with heavy proteinuria in both 7AM sample $(r=0.774$ in group 3) and 7PM sample $(r=0.567$ in group3). This was consistent with the findings of Mohan et $\mathrm{al}^{12}$ who showed that the correlation in type 2 diabetics and Leung et $\mathrm{al}^{13}$ who studied the correlation in lupus nephritis decreased with increasing degree of proteinuria. But Agarwal et al found excellent correlation in all degrees of proteinuria. ${ }^{14}$

Analysing by segregating the patients into 5 different groups based on stages of chronic kidney disease, there was significant positive correlation in patients with normal or milder degrees of renal dysfunction which decreased as the renal function deteriorated. This is 
similar to the findings of Siwach et al but differing from the findings of Sharma et al who observed a good positive correlation even in patients with advanced renal failure. ${ }^{15,16}$ Goldman postulated that the possible reason for poor correlation is these patients is that with progression of renal failure the urinary creatinine excretion falls, especially after serum Creatinine exceeds $6 \mathrm{mg} / \mathrm{dl} .{ }^{17}$ This was further observed in multiple studies that there was erratic and decreased excretion of creatinine in patients with advanced renal failure. ${ }^{18-20}$

\section{CONCLUSIONS}

A good correlation was found between 24 hours urine protein excretion and protein- creatinine ratio taken at two different times of the day although early morning sample correlated better than evening sample. The better correlation was observed in patients with non nephrotic range proteinuria with normal / mild renal dysfunction. Correlation was least in patients with nephrotic range proteinuria with moderate severe renal dysfunction. This study supports the use of a single voided ProteinCreatinine ratio to predict 24 hours urine protein. It avoids collection errors, less time consuming and is suitable for outpatient departments.

Funding: No funding sources

Conflict of interest: None declared

Ethical approval: The study was approved by the Institutional Ethics Committee

\section{REFERENCES}

1. Carroll MF, Temte JL. Proteinuria in Adults: A Diagnostic Approach. Am Fam Physician. 2000;62(6):1333-40.

2. Denker B, Brenner B. Azotemia and Urinary abnormalities. Harrison's Principles of Internal Medicine. $17^{\text {th }}$ edition. McGraw - Hill medical publishing division, 2008

3. Cameron JS. The Patient with Proteinuria and/or haematuria. Oxford Textbook of Clinical Nephrology, $3^{\text {rd }}$ edition. Oxford Medical Publication, 2005.

4. Keane WF. Proteinuria: its clinical importance and role in progressive renal disease. Am J Kidney Dis. 2000;35;S97-105.

5. Keane WF, Eknoyan G. Proteinuria, Albuminuria, Risk, Assessment Detection, Elimination (PARADE): A position paper of National Kidney Foundation. Am J Kidney Dis. 1999;33:1004-10.

6. Price CP, Newall RG, Boyd JC. Use of Protein: Creatinine Ratio Measurements on Random Urine Samples for Prediction of Significant Proteinuria: A Systematic Review. Clin Chem. 2005;51(9):157786.

7. Kerr DN. Normal values in Renal Medicine. Medicine. 1982;23:1047.
8. Silink M, Cowell CT, Rogers S. First Morning urinary albumin concentration is a good predictor of 24 hours urinary albumin excretion in patients with type I (insulin dependent) Diabetes. Diabetologia. 1986;29:697-99.

9. Gisberg JM, Chang BS, Matarese RA, Garella S. Use of single voided urine sample to estimate quantitative proteinuria. $\mathrm{N}$ Eng $\mathrm{J}$ Med. 1983;309:1543-6.

10. Rodby RA, Rohde RD, Lewis EJ, Sharon J, Pohl MA, Bain RP. The ratio as a predictor of 24 hour urine protein excretion in Type I diabetic patients with Nephropathy. Am J Kidney Dis. 1995;26:9049.

11. Koopman MG, Krediet RT, Koomen GC. Circadian Rhythm of proteinuria: Consequences of the use of urinary protein Creatinine ratio. Nephrol Dial Transplant. 1989;4:9-14.

12. Mohan V, Merra R, Premalatha G. Frequency of proteinuria in type 2 Diabetics seen at a Diabetic center in Southern India. Post Grad Med J. 2000;76:569-573.

13. Leung YY, Szeto CC, Tam LS, Lam CWK, Li1 EK, Wong KC. Urine protein-to-creatinine ratio in an untimed urine collection is a reliable measure of proteinuria in lupus nephritis. Rheumatology. 2007;46:649-52.

14. Agarwal I, Kirubakaran C, Markandeyulu and Selvakumar. Quantitation of proteinuria by spot urine sampling. Ind J Clin Biochem. 2004;19(2):457.

15. Siwach SB, Karla OP, Sharma R, Singh V, Chopra JS. Estimation of 24 hour protein exerction from single random urine specimen. Ind $\mathrm{J}$ Med Red. 1990;92:105-8.

16. Sharma BK, Jain PK, Jindal SK. Urinary protein excretion in normal Indian subjects. Ind J Med Res. 1981;74:286.

17. Goldman R. Creatinine excretion in renal failure. Procs exp Biol Med. 1954;85:446.

18. Carrie BJ, Golbetz HV, Michaels AS, Myers BD. Creatinine: an inadequate filtration marker in glomerular diseases. Am J Med. 1980;69(2):177-82.

19. Perrone RD, Madias NE, Levey AS. Serum creatinine as an index of renal function: new insights into old concepts. Clin Chem. 1992;38(10):1933-53.

20. Levey AS, Perrone RD, Madias NE. Serum creatinine and renal function. Annu Rev Med. 1988;39:465-90.

Cite this article as: Naufal Rizwan TA, Sarfaraz Ahmed TA, Kannan R, Senthil Manikandan TJ, Prasanna Karthik S, Mahendrakumar K. A comparative study of spot urine versus 24 hour urine in assessment of proteinuria in varying degree of Renal dysfunction. Int J Adv Med 2016;3:1-4. 